\title{
On the challenges of dating alluvial sediments with radiocesium: a caveat from the Wurm River, Central Europe
}

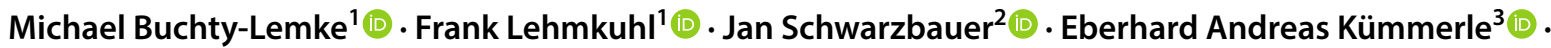 \\ Sven Sindern ${ }^{4}$
}

Received: 24 July 2019 / Accepted: 29 October 2019 / Published online: 7 November 2019

(c) Springer Nature Switzerland AG 2019

\begin{abstract}
The activity of radiocesium in alluvial sediment is a widely used proxy for sediment age determination for the period after its first occurrence in the environment in 1952. In a continuous and undisturbed sediment archive, the results of this method are reliable as shown by various studies. However, depending on the specific characteristics of an archive provided by alluvial sediment, the results might be unreliable or biased. This article describes the challenges and ambiguous results obtained by the measurement of radiocesium in a soil profile that provides a time marker with a concrete structure of known age. The applicability of radiocesium for the study area was successfully tested on a floodplain profile. The results showed radiocesium peaks up to $22.5 \mathrm{~Bq} / \mathrm{kg}$ that correspond to the years 1963 and 1986 . As a result of different hydromorphological conditions and sedimentation rates at the sampling locations, the peaks occurred in different depths. In the floodplain, the ${ }^{137} \mathrm{Cs}$-peaks are significantly more distinguished than in the profile at the concrete structure. There, the radiocesium content is scattered, which queries the function of the structure as a chronological marker. The scattering might be caused by various syn-sedimentary and post-sedimentary processes and factors, such as scouring and redeposition of contaminated sediment, topsoil recycling by vegetation uptake and dieback, or input of eroded sediments from the hinterland forest soils. Thus, the concrete structure creates and at the same time destroys the possibility of using it as a chronological marker.
\end{abstract}

Keywords ${ }^{137} \mathrm{Cs} \cdot$ Chronological marker A Alluvial sediment $\cdot$ Stratigraphy $\cdot$ Sediment chronology $\cdot$ Sediment age determination

\section{Introduction}

\subsection{Radiocesium activity for sediment age determination}

The activity of ${ }^{137} \mathrm{Cs}$ in sediment and soil is widely used as a chronological marker for the past decades. It has been applied for sediment chronologies and determination of sediment accumulation rates in a high variety of sediments (e.g. [1-7 and references therein]. According to [8], radiocesium is a useful marker for assessing rates of sediment accumulation in sediment sinks and serves as a casual tracer for environmental processes [9].

The anthropogenic short-lived radioactive isotope ${ }^{137} \mathrm{Cs}$ with a half-life of approximately 30 years was released in the atmosphere during three major phases: (1) the

Michael Buchty-Lemke, buchty@geo.rwth-aachen.de; Frank Lehmkuhl, flehmkuhl@geo.rwth-aachen.de; Jan Schwarzbauer, jan.schwarzbauer@emr.rwth-aachen.de; Eberhard Andreas Kümmerle, E.Kuemmerle@fz-juelich.de; Sven Sindern, sindern@ iml.rwth-aachen.de | ${ }^{1}$ Department of Geography, RWTH Aachen University, Templergraben 55, 52056 Aachen, Germany. ${ }^{2}$ Institute of Geology and Geochemistry of Petroleum and Coal, RWTH Aachen University, Lochnerstraße 4-20, 52056 Aachen, Germany. ${ }^{3}$ Department of Safety and Radiation Protection, Forschungszentrum Jülich GmbH, 52425 Jülich, Germany. ${ }^{4}$ Institute of Applied Mineralogy and Economic Geology, RWTH Aachen University, Wüllnerstraße 2, 52065 Aachen, Germany. 
beginning of nuclear weapon testing programs by the USA and USSR in 1952 [10], and the first significant atmospheric increase in the northern hemisphere in 1954 [11], (2) the peak of the atmospheric weapon tests in 1963, and (3) the Chernobyl accident in $1986[3,12]$. Subsequent to the input to the pedosphere via fallout (dry and wet deposition), the radiocesium is adsorbed quickly and irreversibly to clay minerals and organic matter $[9,13,14]$. Age determination with radiocesium can be an alternative to more common techniques such as radiocarbon dating. Dating with ${ }^{137} \mathrm{Cs}$ is often combined with the ${ }^{210} \mathrm{~Pb}$ dating technique. In soils and sediments, ${ }^{210} \mathrm{~Pb}$ originates from in situ decay of ${ }^{226} \mathrm{Ra}$ as well as from atmospheric deposition of this radionuclide formed in the decay of gaseous ${ }^{222} \mathrm{Rn}$. Decreasing activity of the latter, excess or unsupported ${ }^{210} \mathrm{~Pb}$ with increasing depth is a basic observation allowing calculation of the ages of individual layers as well as of the sedimentation rate [e.g. 15]. However, quantification of sedimentation rates does not only depend on radioactive decay of excess ${ }^{210} \mathrm{~Pb}$ and initial fallout radionuclide activity related to atmospheric deposition. In dynamic sedimentary systems, such as floodplain deposits characterized by episodic sedimentation, this also depends on input, removal or mixing (physical or biological) of excess ${ }^{210} \mathrm{~Pb}$ adsorbed to detrital particles, possibly even derived from different sources $[16,17]$. Consequently, determination of sedimentation rates on the basis of excess ${ }^{210} \mathrm{~Pb}$ activity requires modelling to account for these different processes.

In contrast to the ${ }^{210} \mathrm{~Pb}$ dating method, application of ${ }^{137} \mathrm{Cs}$ yields independent chronological information.
Provided that element mobility can be neglected, the presence of marked peaks in the depth distribution of this radionuclide can be attributed to the above-mentioned emission events representing time marks independent on modelling and uncertainty inherent in determination of the input parameters-particularly in the case of highly variable flood-related sedimentation $[6,18,19]$. Thus, ${ }^{210} \mathrm{~Pb}$ dating was not considered appropriate for this study.

This decision is based on the morphological position of the sampled profiles, which are within the riparian area of the river and are, therefore, subject to frequent floods. However, if radiocesium dating is applied in alluvial sediments, there are crucial factors to be considered when interpreting the results of a gamma spectrometry analysis.

\subsection{Background}

The so-called Westwall (also known as 'Siegfried Line') is a defence structure from World War II that was built in the period of 1938 to 1940 [20]. Although partly destroyed, large parts of the Westwall still exist. In the area of the city of Aachen, a concrete tank trap was built in the floodplain of the Wurm River (Lower Rhine Embayment, Germany/ Netherlands; see [21]). At some point over the decades, the concrete structure began to submerge into the floodplain sediments to complete coverage in the river bank (Figs. 1, 2b-d). As the construction year of the particular tank trap is known (=1939), this field observation suggested the research question whether it is possible to use the concrete tank trap as a landmark for evaluating subsidence that occurred after the decline of coal mining in the

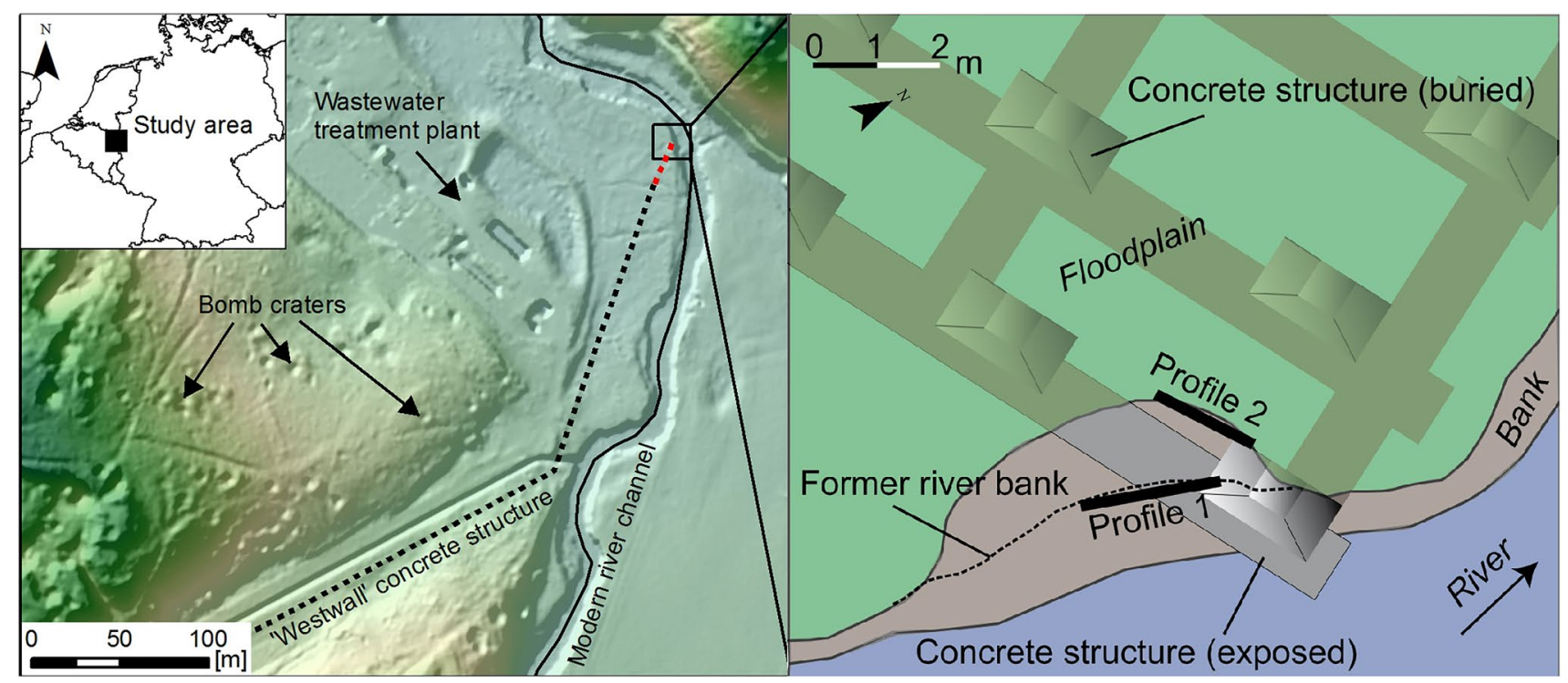

Fig. 1 Study site overview (left) and draft of the field situation (right) with the concrete structure profiles at the Westwall site sampled in 2013 and 2018 (plan view) 
Fig. 2 a Relief changes 1895-2012 in $\mathrm{m}$ and the location of the sampling sites, b Westwall original appearance (off-site) [24], c Westwall submerging into sediment (onsite; view direction towards the river) [24], $\mathbf{d}$ bank profile; view from the opposite bank; the Westwall runs towards the left of the picture
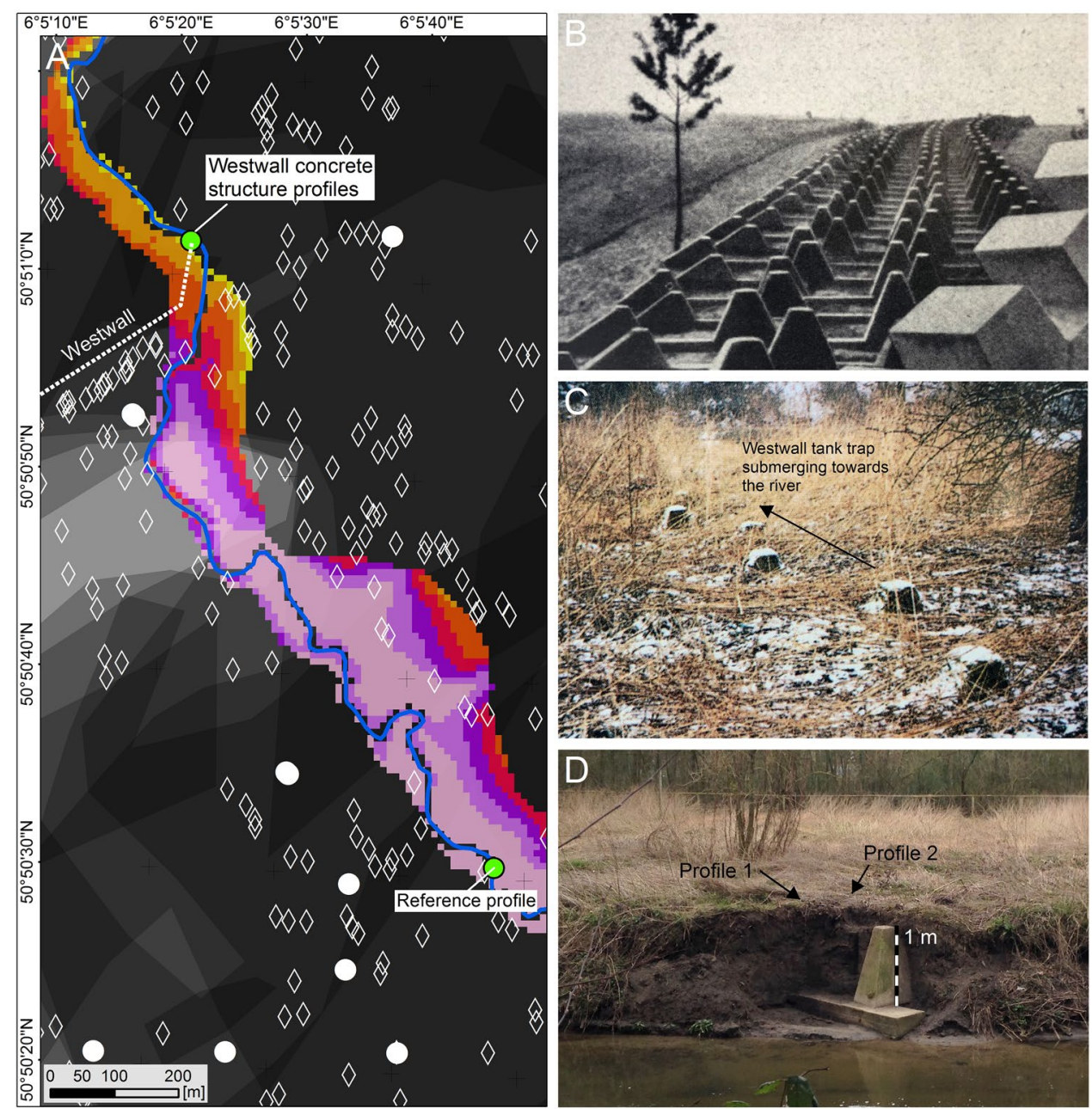

Relief changes from 1895 to 2012 [m]
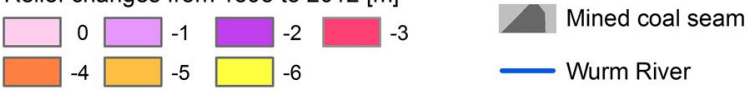

Sinkhole caused by mining

Mineshaft twentieth century in the study area [see 22, 23]. With this period and the environmental and morphological setting of the study site, age determination with radiocesium was the most promising method to determinate the sedimentation sequence. Historical maps suggest that at the time of the fallout events described above, the concrete structure was exposed on a point-bar surface. With ongoing accumulation of point-bar sediments and a subsequent change from lateral accumulation to overbank deposition, the surface elevation rose, causing a decrease in flooding recurrence interval.

\subsection{Objective}

According to the above considerations, this article aims at estimating sedimentation rates, or subsidence rates, respectively, and discusses the issues and complexity that emerge with radiocesium dating in highly dynamic riparian environments. This case study is related to other publications concerning the Wurm River that were part of a research project funded by the Deutsche Forschungsgemeinschaft. The research project aimed at investigating the pre-industrial to post-industrial human impact on small river catchments in Central Europe by the example of the Wurm River; see [21, 23, 25, 26]. In this context, riparian profiles were sampled and measured for radiocesium dating. On the basis of a floodplain profile, the applicability of radiocesium dating in the study area was verified. The actual target profile in between the concrete tank trap was sampled to assess the subsidence of the structure. In an unpublished master's thesis (Krauser 2012), subsidence rates were derived from a comparison of historical maps and the recent digital elevation model (Fig. 2a). The verification was unsuccessful in the first attempt, as the measurement results were not suitable for an interpretation. Therefore, the profile was sampled a second time later on. 
The unsatisfactory data situation raised the question of the extent to which the methodology is applicable here and in comparable alluvial sediments.

\section{Methods}

To verify whether dating with ${ }^{137} \mathrm{Cs}$ is applicable in the study area, a riparian profile was created in the vicinity of the actual target site of the study, which is the Westwall concrete structure. This reference profile was created $1.4 \mathrm{~km}$ upstream; the site was chosen for being the closest to the Westwall profile available for sampling, and, furthermore, including sharply defined natural levee sediments with a presumed age consistent with the period of investigation. The profile at the Westwall was created in between the pyramid-shaped tank trap concrete structure that was laterally exposed in the river bank [see 26]. The floodplain and Westwall profiles were then sampled in 5-cm intervals for grain size and elemental analysis. For ${ }^{137} \mathrm{Cs}$ activity measurement via gamma spectrometry, the Westwall profile was sampled from 22 to $87 \mathrm{~cm}$ depth, and the floodplain profile from 10 to $65 \mathrm{~cm}$ depth; sampling resolution was $1 \mathrm{~cm}$ in both profiles.

Because of the riparian environment that is characterized by episodic and highly variable flood-related deposition, there were no models used for calculating sedimentation rates. Instead, the rates were calculated by dividing the sediment thickness above radiocesium peaks in $\mathrm{mm}$ by the time between the radiocesium emission year and the sampling year [see 27].

Because of the insufficient data lacking a zero-content of radiocesium at the bottom of the sample track, a second profile was sampled later on in a similar position but rotated approx. 35 to $45^{\circ}$ and shifted 50 to $60 \mathrm{~cm}$ backwards, as the riverbank has been further eroded in the meantime (Fig. 1). The morphological position with regard to the river, however, remained the same. The second sampling was done to the maximum possible depth of $135 \mathrm{~cm}$ from the topsoil to the gaps between the tank trap footings. Sampling interval was 2.5 to $5 \mathrm{~cm}$.

The tank trap was laterally exposed in a river bank that was $140 \mathrm{~cm}$ high; in the floodplain, the concrete structure was fully covered with alluvial sediment (Fig. 1). According to the flood risk map, the area is inundated in case of a 20-year flood [28]. The floodplain was covered with herbaceous perennials and shrubs. The profile revealed anthropogenically undisturbed natural alluvial structures, mainly point-bar sediments in the lower part and overbank deposits in the upper part; fine sand content was between 50 and $80 \%$, silt content between 15 and $55 \%$, and clay content between 3 and $8 \%$. The reference floodplain site is inundated in case of a 50-year flood [21] and covered with grass. A sharply delineated natural levee is underlain by buried topsoil and unstructured fine sand subsoil. The proportions of fine sand, silt, and clay are comparable to the Westwall profiles. Anthropogenic disturbances are absent. The measurement of the ${ }^{137} \mathrm{Cs}$ activity was performed by gamma spectrometry. The sediment samples were homogenized; roots and stones were removed. Samples were dried at $105^{\circ} \mathrm{C}$ for a minimum of $24 \mathrm{~h}$ and then weighed. For the analysis, high-purity germanium detectors (HPGe, from ORTEC and Canberra) in a low-level shielding with relative efficiencies of $30-70 \%$ were used; counting time was $15 \mathrm{~h}$. Calibration of the detector efficiencies was done using a certified geometry reference source containing the nuclides ${ }^{133} \mathrm{Ba},{ }^{57} \mathrm{Co},{ }^{139} \mathrm{Ce},{ }^{85} \mathrm{Sr},{ }^{137} \mathrm{Cs},{ }^{54} \mathrm{Mn},{ }^{65} \mathrm{Zn}$, and ${ }^{88} \mathrm{Y}$. The average uncertainty was $0.03 \mathrm{~Bq} / \mathrm{kg}$ for gamma activity below $0.5 \mathrm{~Bq} / \mathrm{kg}, 0.04 \mathrm{~Bq} / \mathrm{kg}$ for gamma activity between 0.5 and $0.7 \mathrm{~Bq} / \mathrm{kg}$, and $0.05 \mathrm{~Bq} / \mathrm{kg}$ for gamma activity above $0.7 \mathrm{~Bq} / \mathrm{kg}$.

\section{Results}

The floodplain profile (Fig. 3, left) was characterized by two peaks ( 21.5 and $22.3 \pm 0.05 \mathrm{~Bq} / \mathrm{kg}$ ) at depths of 27 and $41 \mathrm{~cm}$ that corresponded to the major radiocesium emission phases $(1963=$ max. emission by nuclear weapons testing; $1986=$ emission by Chernobyl disaster). At $52 \mathrm{~cm}$ and downwards to the lowest sampled depth of $63 \mathrm{~cm}$ below the floodplain surface, the ${ }^{137} \mathrm{Cs}$ signal decreased to zero. In contrast, the results for the ${ }^{137} \mathrm{Cs}$ activity in the two concrete structure profiles (Fig. 3, middle and right) showed an ambiguous and unclear pattern, scattered, with peaks up to $14.3 \pm 0.05 \mathrm{~Bq} / \mathrm{kg}$ (concrete structure profile $1,82.5 \mathrm{~cm}$ depth) and $22.0 \pm 0.05 \mathrm{~Bq} / \mathrm{kg}$ (concrete structure profile $2,100 \mathrm{~cm}$ depth); a decrease to zero radiocesium activity cannot be observed. The depth gradient of the radiocesium signal was comparable in both concrete structure profiles with differences in the range of $2-3 \mathrm{~cm}$ in depth due to the slightly different positions of the profiles (see Fig. 1). For example, the peak at $85 \mathrm{~cm}$ depth in profile 1 corresponds to the peak in profile 2 in a depth of $82.5 \mathrm{~cm}$. Differences in the gamma activity curves are caused by the different sampling resolutions: the more detailed measurement in profile 1 is smoothed by the coarser resolution in profile 2 . In profile 1 , four slightly established peaks could be recognized at $23,33,61$, and $85 \mathrm{~cm}$ depths. In profile 2 , slightly elevated contents were present in a curved shape between 12 and $30 \mathrm{~cm}$ depth. At 82.5 and $100 \mathrm{~cm}$ depth, the radiocesium contents showed Cs-peaks up to $22.0 \mathrm{~Bq} / \mathrm{kg}$, exceeding the average gamma activity by the factor of two. 


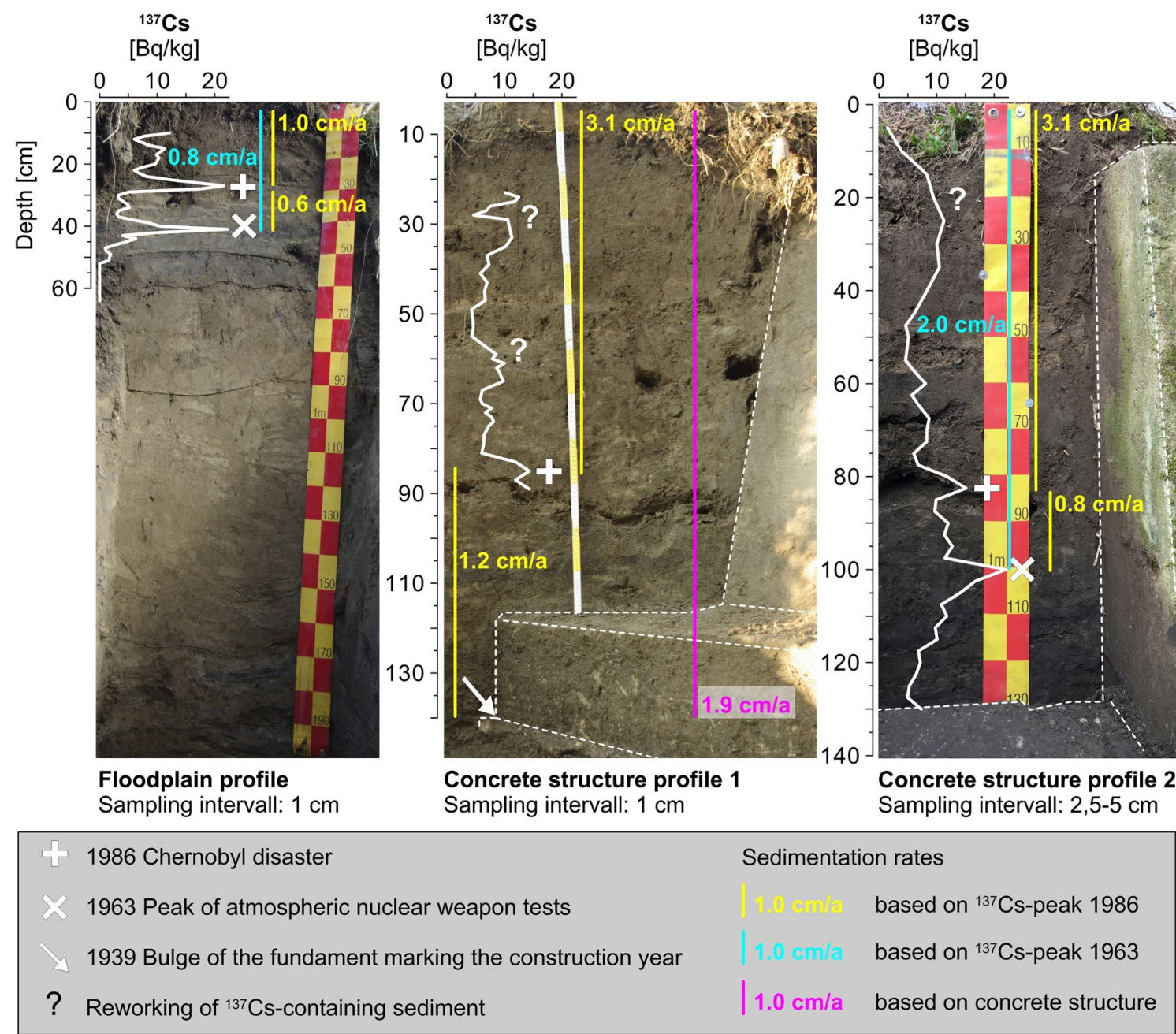

Fig. 3 Results of the radiocesium activity measurement for the reference floodplain profile (left) and for the two concrete structure profiles (middle and right). The signal in both Westwall profiles is ambiguous, and there is no decrease to zero-content at the base of the sample line. In comparison, the floodplain profile exhibits two clear peaks and a zero-signal in the lower sample line. The dashed line marks the Westwall concrete structure

\section{Discussion}

From the results, the following estimations for sedimentation rates can be derived:

- In the floodplain profile (Fig. 3, left), the gamma activity shows a clear pattern with two distinct peaks of radiocesium. Therefore, the undisturbed sediment with a sharply delineated natural levee provides a valuable archive for gamma activity and hence provides reliable age information. When the radiocesium time markers are converted into sedimentation rates, these rates are $0.6 \mathrm{~cm} / \mathrm{a}$ between 1963 and 1986, and $1.0 \mathrm{~cm} / \mathrm{a}$ between 1986 and 2013. Compared to studies at the adjacent catchment of the Geul River by [29, 30], these rates are realistic for the given environmental setting.
- In the concrete structure profile 1 (Fig. 3, middle), the gamma activity shows an ambiguous pattern, characterized by poorly developed peaks $\geq 10 \mathrm{~Bq} / \mathrm{kg}$ and oscillating values between 4 and $8 \mathrm{~Bq} / \mathrm{kg}$. This pattern might be caused by the remobilization and redeposition of contaminated sediments, either by scouring and filling of ex situ sediments, or by in situ mixing — or by a combination of both. The peak $\geq 14 \mathrm{~Bq} / \mathrm{kg}$ in the lower part of the profile can be assigned to the Chernobyl disaster in 1986, as it corresponds to the same peak in concrete structure profile 2 . Therefore, the following sedimentation rates can be assumed: from the fundament of the concrete structure built in 1939 to the gamma activity peak assigned to 1986 , the rate is $1.2 \mathrm{~cm} / \mathrm{a}$. From the activity peak to the floodplain surface from 2013, the rate is $3.1 \mathrm{~cm} / \mathrm{a}$. From the concrete fundament to the ground surface without referring to 
the measurement data, the rate is $1.9 \mathrm{~cm} / \mathrm{a}$-this rate largely corresponds to the average rate of $2.15 \mathrm{~Bq} / \mathrm{kg}$ derived from the radiocesium content.

- In the concrete structure profile 2, the gamma activity curve is similar to profile 1 but smoothed. A second peak of $22 \mathrm{~Bq} / \mathrm{kg}$ that might correspond to the atmospheric nuclear weapon tests in 1963 is present in $100 \mathrm{~cm}$ depth. The gamma activity does not decrease to zero in the bottom part in between the fundament. According to the gamma activity, the sedimentation rate is $0.8 \mathrm{~cm} / \mathrm{a}$ from 1963 to 1986 , and $3.1 \mathrm{~cm} / \mathrm{a}$ from 1986 to 2013 . The average sedimentation rate is $2.0 \mathrm{~Bq} /$ $\mathrm{kg}$, which is in accordance with the average rate of profile 1.

- With average rates of $0.8 \mathrm{~Bq} / \mathrm{kg}$ at the reference floodplain site and an average for both Westwall profiles of $2.1 \mathrm{~Bq} / \mathrm{kg}$, the sites differ by a factor of approximately 2.5. Therefore, we conclude that the sedimentation at the Westwall site was about twice as high as at the reference site. As both sites are part of the same river segment characterized by the same environmental conditions, sediment input, and discharge, we conclude that the doubled sedimentation is caused by a subsidence of the Westwall site. Given the circumstances thataccording to historical maps-the concrete structure was in a point-bar position during the radiocesium emission phases, a scenario where $3.1 \mathrm{~cm} /$ a sediment deposition takes place without subsidence is unlikely. Although the flooding interval is twice as high as at the reference site (50 years at the reference floodplain compared to 20 years at the Westwall site, see methods section), an abrupt increase in sedimentation from 1963 onwards by a factor of almost 4 is implausible.

In the following, factors and circumstances that might have an influence on the vertical radiocesium distribution at the study site are explained. Because every study site is different for a variety of reasons, the observations are not necessarily comparable to every similar floodplain, but they are generally transferable.

- Détriché et al. [27] found that at the River Loire, sandy particles can lead to a substantial retention of radiocesium. However, in our study, a relation between the texture of the sediment and the gamma activity cannot be observed. The proportion of sand in the sampled profiles varies between 40 and $80 \%$, but the gamma activity is independent from these variations.

- At the Westwall profile, alluvial deposition took place within a geometric concrete structure with perpendicular shapes and cavities in the footing. Therefore, the aggradation that filled up the space in the structure was most likely discontinuous, as the flow conditions are highly variable, creating scours, in situ resuspension and subsequent sedimentation. Therefore, one or more hiatus is to be expected, and the sedimentological evidence might be biased and unreliable.

- In freshly accumulated alluvial sediments, the majority of the ${ }^{137} \mathrm{Cs}$ is adsorbed to amorphous Fe-oxyhydroxides or organic matter [31]. Therefore, the maturity of the soil is a driver for the capacity to adsorb radiocesium. In young sediments with weak pedogenesis, a higher amount of radiocesium is adsorbed, as the amount of Fe-oxyhydroxides such as ferrihydrite is higher. Soils with organic-rich $\mathrm{O}, \mathrm{Ah}$, or Bh horizons, organic-rich muds or peat are likely to adsorb high amounts of radiocesium as well. According to [32], bog-like alluvial soils tend to incorporate significant higher amounts of radiocesium. Therefore, the alluvial sediment in the Westwall profile, in which pedogenetic processes play a minor role, and the interbedded organic-rich layers might influence the vertical radiocesium distribution.

- As described by [15], soil processes such as bioturbation, leaching, diffusion, and translocation might contribute significantly to a redistribution of radiocesium. As the Westwall profiles are in a lower hydromorphological position than the reference floodplain profile, alternations of the groundwater table might cause particle redistribution.

- According to [33], forest soils are hot spots of radiocesium contamination. Hence, since the valley slopes are forested, there might appear a pulsed input of contaminated sediment through erosion during heavy rainfalls, flushing sediment enriched in radiocesium into the river system. This might result in a biased radiocesium depth profile, when contaminated sediment is deposited above the layers that correspond to the fallout period. This effect might not apply to the control profile because of a higher distance to the valley slope.

- Horizontal distribution and vertical redistribution of radiocesium seems to be related with seasonal microbial activity (Kostyuk and Bunnenberg 1999 in [14]). Kagan and Kadatsky [34] showed that after 10 years of a fallout event, up to $90 \%$ of the initial radiocesium input remains in the topsoil. In sandy soils, plants tend to an increased uptake of radiocesium [14]. Accordingly, the densely vegetated study site and the sandy substrate might lead to a 'topsoil recycling', in which the radiocesium input is circulated between plant uptake and input from vegetation dieback. This process would cause a continuing ascendant redistribution of the ${ }^{137} \mathrm{Cs}$ in the rooted soil, changing the vertical position of the ${ }^{137} \mathrm{Cs}$-peaks and spreading the distribution into a broader, undefined signal. In comparison, the reference site is used for grazing; therefore, the principle 
described above does not apply and the radiocesium peaks are more defined.

- In case of a fallout event on fresh overbank deposits, the rainwater might percolate through the uppermost sediment layer to an underlaying organic-rich or clay mineral-rich topsoil, where the radiocesium is adsorbed [see 15]. Accordingly, the ${ }^{137} \mathrm{Cs}$-peak might underestimate the sediment age, as the peak appears in a lower layer than the corresponding surface at the time of the fallout event. Based on a visual assessment of the Westwall profile, the radiocesium signal is elevated in slightly darker layers. However, the analytical results show no evidence for higher organic carbon contents in those layers.

\section{Conclusions}

The idea to use a concrete structure with a known construction date as a landmark for sedimentation history seems to be a promising approach. However, the results from the radiocesium activity age determination are surprising and not truly satisfactory. Compared to the reference profile, which shows clear radiocesium peaks and thus confirms the applicability of radiocesium dating in the study area, the results of the Westwall profiles are significantly less differentiated. The secondary effects of the interplay between the concrete structure and the alluvial aggradation, or the modification of flow conditions and aggradation processes, respectively, seems to destroy the continuous radiocesium signal and creates evidence that is ambiguous. The ${ }^{137} \mathrm{Cs}$ signal in the investigated sediment might have been altered by a variety of abiotic and biotic factors that are dependent and independent from the concrete structure and affected by the specific parameters of the study site. Some aspects that apply to a wider range of future studies using radiocesium can be pointed out:

- Alluvial sediments with embedded concrete structures are not suitable for sediment age determination with radiocesium activity measurement. The concrete structure itself is both giving the opportunity to reconstruct the sedimentation history and hindering the sediment age determination via radiocesium activity as a result of its impact on sedimentation processes.

- Studies that used radiocesium for age determination in alluvial sediments rarely provide discussions about the syn-sedimentary conditions of the deposition during the fallout occurrences, the detailed sediment parameters, or post-depositional mobility. In the authors' opinion, such information must be considered when interpreting radiocesium results.
- The sediment age determination with radiocesium in alluvial sediment is a well-functioning method if applied on 'reliable' sediment such as natural levee sediment. If the method is to be applied in sediment with multi-factor influence, the results have to be interpreted with caution. However, the usage in highly dynamic environments should be avoided. If the sampled sediment might be eroded infrequently and irregularly, this impedes the ability to reconstruct the sedimentation history. Therefore, the subrecent topography and morphology of the riverscape should be investigated to the most possible extent.

Acknowledgements The authors thank Verena Esser for valuable comments that strongly improved the manuscript. This work was supported by Deutsche Forschungsgemeinschaft (Grant Number LE730/33-1).

Authors' contributions MBL wrote the manuscript and conducted the field work. EK conducted the gamma spectroscopy measurements and was responsible for the methodology section. SS wrote the discussion of applicability of ${ }^{210} \mathrm{~Pb}$. FL, JS, and SS gave advice for data interpretation, verified the scientific validity of the results, and reviewed the manuscript.

\section{Compliance with ethical standards}

Conflict of interest The authors declare that they have no conflicts of interests.

\section{References}

1. Ritchie JC, McHenry JR (1990) Application of radioactive fallout cesium-137 for measuring soil erosion and sediment accumulation rates and patterns: a review. J Environ Qual 19:215-233

2. Edgington DN, Klump JV, Robbins JA et al (1991) Sedimentation rates, residence times and radionuclide inventories in Lake Baikal from ${ }^{137} \mathrm{Cs}$ and ${ }^{210} \mathrm{~Pb}$ in sediment cores. Nature 350:601-604

3. Klös H, Schoch C (1993) Historische Entwicklung einer Sedimentbelastung: gedächtnis einer Industrieregion Historical Trends of Sediment Loads: Memory of an Industrial Region. Acta Hydrochim Hydrobiol 21:32-37

4. Walling $\mathrm{DE}, \mathrm{He} \mathrm{Q}$ (1997) Use of fallout ${ }^{137} \mathrm{Cs}$ in investigations of overbank sediment deposition on river floodplains. CATENA 29:263-282

5. Benninger LK, Suayah IB, Stanley DJ (1998) Manzala lagoon, Nile delta, Egypt: modern sediment accumulation based on radioactive tracers. Environ Geol 34:183-193

6. Humphries MS, Kindness A, Ellery WN, Hughes JC, Benitez-Nelson $\mathrm{CR}(2010){ }^{137} \mathrm{Cs}$ and ${ }^{210} \mathrm{~Pb}$ derived sediment accumulation rates and their role in the long-term development of the Mkuze River floodplain, South Africa. Geomorphology 119:88-96. https ://doi.org/10.1016/j.geomorph.2010.03.003

7. Heim S, Schwarzbauer J (2013) Pollution history revealed by sedimentary records: a review. Environ Chem Lett 11:255-270

8. Brown AG, Carey C, Erkens G et al (2009) From sedimentary records to sediment budgets: multiple approaches to catchment sediment flux. Geomorphology 108:35-47 
9. Korobova E, Linnik V, Chizhikova N (2008) The history of the Chernobyl ${ }^{137} \mathrm{Cs}$ contamination of the flood plain soils and its relation to physical and chemical properties of the soil horizons (a case study). J Geochem Explor 96:236-255

10. Heim S, Schwarzbauer J, Kronimus A et al (2004) Geochronology of anthropogenic pollutants in riparian wetland sediments of the Lippe River (Germany). Org Geochem 35:1409-1425

11. Walker M (2005) Quaternary dating methods. Wiley, Chichester

12. Geyh MA (2005) Handbuch der physikalischen und chemischen Altersbestimmung. WBG, Darmstadt

13. Oktay SD, Santschi PH, Moran JE, Sharma P (2000) The ${ }^{129}$ iodine bomb pulse recorded in Mississippi River Delta sediments: results from isotopes of $\mathrm{I}, \mathrm{Pu}, \mathrm{Cs}, \mathrm{Pb}$, and $\mathrm{C}$. Geochim Cosmochim Acta 64:989-996

14. Kabata-Pendias A (2011) Trace elements in soils and plants, 4th edn. CRC Press, Boca Raton

15. Matisoff G, Whiting PJ (2012) Measuring soil erosion rates using natural $\left({ }^{7} \mathrm{Be},{ }^{210} \mathrm{~Pb}\right)$ and anthropogenic $\left({ }^{137} \mathrm{Cs},{ }^{239,240} \mathrm{Pu}\right)$ radionuclides. In: Baskaran M (ed) Handbook of environmental isotope geochemistry. Springer, Berlin, pp 487-519. https://doi. org/10.1007/978-3-642-10637-8_25

16. Nie Y, Suayah IB, Benninger LK, Alperin MJ (2001) Modeling detailed sedimentary ${ }^{210} \mathrm{~Pb}$ and fallout ${ }^{239,240} \mathrm{Pu}$ profiles to allow episodic events: an application in Chesapeake Bay. Limnol Oceanogr 46:1425-1437

17. Pizzuto J, Skalak K, Pearson A, Bentheim A (2016) Active overbank deposition during the last century, South River, Virginia. Geomorphology 257:164-178

18. Łokas E, Wachniew P, Ciszewski D, Owczarek P, Chau ND (2010) Simultaneous use of trace metals, ${ }^{210} \mathrm{~Pb}$ and ${ }^{137} \mathrm{Cs}$ in floodplain sediments of a lowland river as indicators of anthropogenic impacts. Water Air Soil Pollut 207:57-71. https://doi. org/10.1007/s11270-009-0119-4

19. Du P, Walling DE (2012) Using ${ }^{210} \mathrm{~Pb}$ measurements to estimate sedimentation rates on river floodplains. J Environ Radioact 103:59-75. https://doi.org/10.1016/j.jenvrad.2011.08.006

20. Rohde H (1998) Vom Westwall zur Siegfried-Linie. In: Willems W, Koschik H (eds) Der Westwall—Vom Denkmalwert des Unerfreulichen, 2nd edn. Rheinland-Verlag, Köln, pp 41-66

21. Buchty-Lemke M (2018) Untersuchungen zu anthropogenen Einflüssen auf die fluviale Morphodynamik und die Verteilung erhöhter Spurenelementgehalte in kleinen Flusseinzugsgebieten - Das Beispiel der Wurm, Flussgebietseinheit Maas. Dissertation, RWTH Aachen University. http://publications.rwth-aache n.de/record/749383/files/749383.pdf. Accessed 23 July 2019

22. Buchty-Lemke $M$, Hagemann $L$, Maaß AL, Schüttrumpf $H$, Schwarzbauer J, Lehmkuhl F (2019) Floodplain chronology and sedimentation rates for the past 200 years derived from trace element gradients, organic compounds, and numerical modeling. Environ Earth Sci. https://doi.org/10.1007/s1266 5-019-8428-4

23. Maaß AL, Schüttrumpf $H$ (2018) Long-term effects of mininginduced subsidence on the trapping efficiency of floodplains. Anthropocene 24:1-13
24. Hansen HJ, Jahn J, Jahn M, Lois D (2005) Auf den Spuren des Westwalls - Entdeckungen entlang einer fast vergessenen Wehranlage, 5th edn. Helios, Aachen

25. Buchty-Lemke $M$, Lehmkuhl F (2018) Impact of abandoned water mills on Central European foothills to lowland rivers: a reach scale example from the Wurm River, Germany. Geografiska Annaler: Ser A, Phys Geogr. https://doi.org/10.1080/04353 676.2018.1425621

26. Hagemann L, Buchty-Lemke M, Lehmkuhl F et al (2018) Exhaustive screening of long-term pollutants in riverbank sediments of the Wurm River. Germany. Water Air Soil Pollut 229:197

27. Détriché $S$, Rodrigues $S$, Macaire JJ, Bonté $P$, Bréhéret JG, Bakyono JP, Jugé $P(2010)$ Caesium-137 in sandy sediments of the River Loire (France): assessment of an alluvial island evolving over the last 50 years. Geomorphology 115:11-22. https://doi. org/10.1016/j.geomorph.2009.07.003

28. District Government Cologne-Department 54 Water Management (2012) Flood Risk Map Wurm River-20 year floods (Map 18/22), https://www.flussgebiete.nrw.de/system/files/ atoms/files/2828_wurm_a00_rk_hw_b018.pdf. Accessed 03 Feb 2019

29. Stam MH (2002) Effects of land-use and precipitation changes on floodplain sedimentation in the nineteenth and twentieth centuries (Geul River, The Netherlands). In: Peterrtini I, Baker VR, Garzón $\mathrm{G}$ (eds) Flood and megaflood processes and deposits. Blackwell Publishing Ltd., Oxford, pp 251-267

30. Swennen R, Keer IV, Vos WD (1994) Heavy metal contamination in overbank sediments of the Geul river (East Belgium): its relation to former $\mathrm{Pb}-\mathrm{Zn}$ mining activities. Environ Geol 24:12-21. https://doi.org/10.1007/BF00768072

31. Kaplan DI, Hinton TG, Knox AS (2005) Cesium-137 partitioning to wetland sediments and uptake by plants. J Radioanal Nucl Chem 264:393-399

32. Shcheglov Al, Kliashtorin AL, Tsvetnova OB (2001) Biogeochemical migration of technogenic radionuclides in forest ecosystems: by the materials of a multiyear study in the areas severely contaminated due to the Chernobyl accident. Nauka, Moscow, 234 $\mathrm{p}$

33. Winkelbauer J, Völkel J, Leopold M (2012) A novel approach to monitoring the Cs-137 contamination of forest soils in Bavaria, Germany

34. Kagan LM, Kadatsky VB (1996) Depth migration of chernobyl originated ${ }^{137} \mathrm{Cs}$ and ${ }^{90} \mathrm{Sr}$ in soils of Belarus. J Environ Radioact 33:27-39

Publisher's Note Springer Nature remains neutral with regard to jurisdictional claims in published maps and institutional affiliations. 